\title{
Rural Road Infrastructural Challenges: An Impediment to Health Care Service Delivery in Kabba-Bunu Local Government Area of Kogi State, Nigeria
}

\author{
Gbadamosi, K. T . PhD, FCILT \\ Olorunfemi, S. 0 \\ Department of Transport Management Technology, Federal University of Technology \\ P.M.B 704, Akure, Ondo State, Nigeria
}

\author{
Doi:10.5901/ajis.2016.v5n2p35
}

\begin{abstract}
In spite of the diverse rural development policy programmes designed address improvement in the condition of rural dwellers in Nigeria, the health needs of many of the rural environment are still being hindered due to inadequacy of rural road transport infrastructures. This situation has put the health of the rural dwellers in jeopardy and invariably makes them vulnerable to curable health challenges with known solutions in tertiary health centres in urban areas. Transport infrastructural challenges have made it relatively difficult encourage the required medical and health personnel to be attracted to working the rural areas of the country. The above situation is responsible for the untold hardship rural dwellers are facing in accessing appropriate healthcare. This study examined the rural road transport infrastructural challenges as an impediment to health care service delivery in Akutupa-Kiri village of Kabba Bunu Local Government area of Kogi State. The study was carried out through structured questionnaire and reconnaissance survey to ascertain the situation. The data were presented using descriptive analytical method. Findings revealed that road transport infrastructures is required to support qualitative health care delivery as poor road network and high transport cost has been found to be responsible for problematic access to medical treatment. The poor transport infrastructures and epileptic nature of transport infrastructure situation compounded health workers ability in the handling of health emergencies in the rural areas. The above situation has negatively impacted on health care delivery in the area. The study recommended construction of motorable roads with adequate infrastructures and creation of Agency or Board that could monitor rural infrastructures particularly transport infrastructures to facilitate easy movement and accentuate healthcare delivery in the area on a positive note.
\end{abstract}

Keywords: Transport, Infrastructure, Healthcare, Movement, Rural.

\section{Introduction}

Rural areas are otherwise known as the country side and their main economic activities in most part of Africa in which Nigeria constituted a part is mainly agriculture. Nigeria is predominantly a rural society considering the fact that greater proportion of her populace resides in the rural areas (Ele, 2006; Nwuke, 2004; Ugwuanyi and Chukwuemeka, 2013). Nigeria is ranked among the first ten (10) oil producing nations in the world. Despite Nigeria's activities in the area of oil production a larger proportion of her population still remains heavily dependent on agriculture as main source of employment.

Rural country sides' of Nigeria have not witnessed any meaningful development despite their significant roles in the process of economic emancipation of the country before the advent of oil. Several opinions have been expressed to catalog the neglect of rural areas by the power that be in the provision of infrastructures since independence. Ugwuanyi and Chukwuemeka, (2013); Obguu,(2010); Okakuri, (2006); Olorunfemi and Basorun, (2013) all have demonstrated the impact of lack of basic infrastructural facilities most especially how the neglect of transport sector has resulted in poor quality of life with its attendant implication on rural dwellers access to healthcare facilities judging from inadequacy of accessibility to healthcare facilities and personnel. Transport infrastructural challenge in rural areas of developing countries has been identified as a key restraint in the realization of effective child and maternal healthcare goals.

Anita et al, (2014) has identified the key hindrances for assessing healthcare service to include among others; long distances to facilities, inadequate and unaffordable transport cost, poor quality of care, and poor governance and accountability mechanisms. Anita et al, (2014) has reiterated the need for smooth and prompt vehicles to address health emergence at lower level or higher level of healthcare delivery as the case may be. The absence of road transport infrastructures in most of the rural areas have been a great challenge limiting rural dwellers accessibility to healthcare 
facility, thereby reducing their performance and efficiency (Anita et al, 2014). Akutupa-Kiri is one of the major villages in Kabba-Bunu Local Government area of Kogi State, Nigeria with population of Four thousand seven hundred and twenty five $(4,725)$ people (NPC, 1991).

The area is endowed with abundant fertile soil, good for agricultural produce but has been hindered to perform at its fullest capacity due to the poor road condition. This study provided an insight to the transport infrastructural challenges posing as threat to the provision and access to healthcare facilities in Akutupa-kiri village. The overall objectives of this study is to examine the available style and strategies of transport infrastructural provision and the impact of same on accessing social economic services / infrastructure with particular reference to healthcare facilities.

\section{Research Methodology}

The methodology of study involved the use of primary and secondary. 1991 Population Census figures were used in the determination of the sample size for the study. The Nigerian National Population Commission projected a bench mark of 4725 people with a growth rate of $2.8 \%$ which amounted to 8,918 people in 2014. Taro Yamane's formula was used to establish the sample size, as shown below:

$$
\begin{aligned}
& \mathrm{n}=\frac{N}{1+N(e)^{2}}=\mathrm{n}=\frac{8918}{1+8918(0.08)^{2}} \\
& =156
\end{aligned}
$$

Where: $n=$ Sample size

$\mathrm{N}=$ Population

$\mathrm{e}=$ Level of precision in $\%=$ level of precision or sampling error at 0.08 .

The 156 respondents were selected as the sample population. The household head of the population were sampled. Systematic sample method was used to pick respondent at every $5^{\text {th }}$ interval within the sample population in the study area.

A questionnaire was also designed to elicit vital information from the health officers at the cottage hospital Akutupa-kiri. Univariate analytical technique was used to establish the perception of residents of the area on the impact of transport infrastructures on socio-economic development of the area as well as its impact on access to health care facility.

\section{Conceptual Framework and Literature Review}

To create a context for a clearer appreciation of the discussion and analysis, the following concepts of the study are clarified below:

Transport and Development: The cyclical relation between transport and development has been emphasized by different school of thought and there is no gain saying that transport improves the utility of space and product by ensuring that goods are transported to the location where it can be best be utilized.

Meanwhile, Development is a household concept in both the developed and developing countries (Ugwuanyi, and Chukwuemeka, 2013). Development has been hypothesized by different school of thought. Some see it as a period of change while some see it as a time of new innovation, advancement and improvement. Adewole (2013) see development as period of transformation, advancement to a better and desired state of positive transformation. In relation to the above, Okoli and Onah (2002) state that development has to do with progression, movement and advancement towards something better. They stressed further that the movement include both material and non-material aspects of life. In any case, the prevailing conception of development connotes enhancement in the well-being of people (Okoye, 2000; Ugwuanyi, and Chukwuemeka, 2013). In the actual sense, development entails modernization or westernization (Ele, 2006; Ugwuanyi, and Chukwuemeka, 2013)). For instance, technological innovation has provided unique transformation to the development of transport to overcome the challenge of distance as well as comfort requires to achieving interaction over the year.

However, through transport development, movement across the globe has been made through production of sophisticated vehicle, aircraft and ships. Hence, this type of opportunity is highly beneficial to the urban people while the rural people are totally neglected.

\subsection{Literature Review}

Transport infrastructure is of necessity for the development of any location particularly in accessing healthcare facilities 
and other human activities in space. Several researchers have discussed the challenges facing the rural dwellers particularly in the area of spatial mobility, which is very crucial to the economic and social survival of any community or society. For instance, Annabel (2000) based on his research in Zambia, opines that transport infrastructures appears to be a significant concern for villagers. Fatoke (2013) noted that in most developing countries, locations of healthcare facilities more often than not favours urban area to the neglect of rural area. This implies that urban population enjoying better health services than the rural population who are the majority. This inequity in the distribution of health care facilities is responsible for many health problems prevalent in the rural areas. There is no doubt that rural people who constituted more than $60 \%$ of the nation population lack development in term of physical facilities (Adereti, 2005).

Rural accessibility is also an important factor that should be considered in improving rural dwellers' health and condition. This assertion has been stressed out by authors like Shoup, (2006), Basorun (2004), Okoko (2006), that the ability and propensity of an area or a particular land use types to attract traffic will decline as the land use types or the area becomes more distant or remote from people or materials it is meant to attract. This shows that distance is a trip deterring factor in the sense that longer distance discourages traffic (i.e. the longer the distance the less to traffic experience) (Okoko, 2006). In line with the above, accessibility is seen as important consideration in setting or location of health care centre for the rural dwellers. Upon this, Alabi (2011, Aregbeyan , 1992) in their studies the overall importance of access to healthcare facilities as yardstick for measuring quality of life but this in most cases are constrained by challenges of physical accessibility of a household members to health care facilities in most rural milieu in Nigeria. In fact, it has been stated that the greater the distance between two (2) points, the lower the probability of these points being functionally related (Alabi, 2011). A large number of studies have shown a regular waning in accessibility to health facilities with increasing distance in road transport journeys to hospitals (Alabi, 2011; Barjis, 2013; Anita, 2014). Equally, some studies that were undertaken in different parts of Nigeria have similarly shown variation in maximum distance which people travel to utilize health facilities, for instance, Adejuyigbe (1977) and Adeyemo (2005) noted that there is a limit to the distance, which people are ready to travel in order to enjoy some health services. They further maintained that attendance at each medical centre is a function of both type of services available in the medical centre and the distance from other medical centre providing similar service (Alabi, 2011).

Despite the strategies and policies of the government at all levels of governance in improving the life of rural dwellers with programmes and policies among the programs include; Directorate of Roads and Rural Infrastructure (DFRRI) to enhance infrastructure development in the rural areas, River Basin Development Authorities (RBDAs), Rural Electrification Scheme, Better Life for Rural Women Programme, National Directorate of Employment (NDE), Millennium Development Project targeted at Rural Infrastructure, Rural Banking Programme, and provision of Micro credit Finance to provide financial support for rural economy and provide financial services to the rural poor. (Ajadi, 2010; lyagba and Anyanwu, 2012; Ugwuanyi and Chukwuemeka, 2013). It is unfortunate that all this efforts has not yielded any improvement in the quality of life of rural dwellers. The ineffectiveness of government policy programmes may not be unconnected with corrupt practices among government officials as reported by Ezeah, (2005); Ugwuanyi and Chukwuemeka (2013), Adeewole (2013) .

\section{Study Area}

Akutupa Kiri is a town in Kabba/Bunu Local Government of Kogi State in central region of Nigeria and is situated at $8^{\circ} 27^{\prime} \mathrm{N} 6^{\circ} 24^{\prime} \mathrm{E}$ with population of 4,725 . The language of Akutupa- kiri isYoruba while their local language is called Kiri and their traditional occupations is farming (Sibiri et al, 2014).

The road that links Akutupa-Kiri is a Federal road that transverse through lluke-Bunu and terminated at Egan in Lokoja Local Government Area of Kogi State. Having realized the socio-economic activities of the people along the route, the federal Government approved the construction of the road from Ayetoro- Gbede in ljumu Local Government to Eggan in Lokoja Local Government Area of Kogi State respectively. The construction stated in 2001 and about 50km of the road was constructed and this terminated at Suku in Kabba-Bunu Local Government area of the state, while other part of the road was abandoned up to this moment. This situation has worsened the mobility of people residing along the route (Akutupa-Kiri inclusive) and has great effects on their trading activities and healthcare services. Akutupa-Kiri has a cottage Hospital but the condition of the road has affected the operational efficiency of the centre due to poor road, lack of mobile network and other social amenities that could have aid the development in the area. The map below shows the kabba-Bunu Local Government in its National Setting and Akutupa-Kiri the study location 


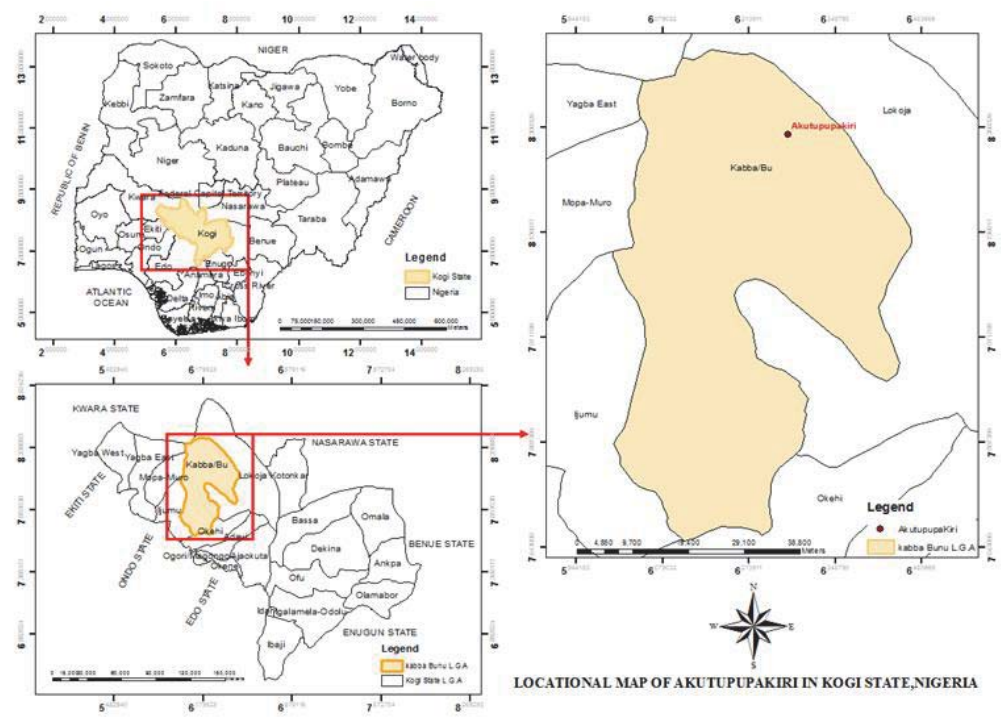

Source: Kogi State Town Planning Board, Lokoja and modify by Authors 2014

\section{Data Presentation and Discussion}

\subsection{Socio-Economic Characteristic of the Respondents}

The analysis in Table 1 shows the socio-economic characteristics of the respondents in Akutupa-kiri, the study location. It was revealed in the analysis that females were $62.8 \%$ while the males were $37.2 \%$ in the study area. This is a confirmation of the 1991 population census statistics which revealed that females are more than their males' counterpart in the area. The marital status of the respondents' shows that majority (64.10\%) of the people in the area are married. It was reflected that $35.2 \%$ of the respondents fall between ages $51-60$ years. The educational background of the respondents reveals that majority (61.0\%) had primary school education and $23.1 \%$ are without formal. This type of level of education is so synonymous to the rural area simply because many of them give up at this stage and settle for other means of livelihood particular farming or trading. In corroboration with the above Olorunfemi (2013) opines that this is the limit of free education opportunity in Nigeria and where education is still affordable by the average poor. In most cases, those who meet requirements for higher education give up at this stage for businesses because of the cost involved.

The occupational status reveals that majority $(60.3 \%)$ are farmers while quite number of them also involved in trading activities for their survival. This is attributed to fact that rural area is mostly characterized as an agrarian region as majority of her populace remains heavily dependent on agriculture as main source of employment. Analysis into the annual income shows that majority (60.3\%) of the respondents earned between N200,001- N300,000 annually. This implies that majority of the respondents still live below average living standard as indicated by the United Nation and this may affects the people's standard of living, health condition and their ability to demand for housing and requirement for other services Olarenwaju, (1996); Agbola, and Agunbiade (2007).

Table 1: Socio-Economics Characteristics of the Respondents

\begin{tabular}{llcc}
\hline S/N & Socio-Economic Characteristics & Frequency & Percentage \\
\hline & Sex & & \\
1. & Female & 98 & 62.8 \\
2. & Male & 58 & 37.2 \\
& Total & 156 & 100.0 \\
& Marital Status & & \\
\hline
\end{tabular}




\begin{tabular}{|c|c|c|c|}
\hline 1. & Single & 12 & 7.7 \\
\hline 2. & Married & 100 & 64.10 \\
\hline 3 & Divorced & 15 & 10.2 \\
\hline \multirow[t]{3}{*}{4.} & Widowed & 29 & 18.5 \\
\hline & Total & 156 & 100.0 \\
\hline & Educational Status & & \\
\hline 1. & No Formal Education & 36 & 23.1 \\
\hline 2. & Primary School & 95 & 61.0 \\
\hline 3. & Secondary School & 20 & 12.8 \\
\hline \multirow[t]{3}{*}{4.} & Tertiary & 5 & 3.0 \\
\hline & Total & 156 & 100.0 \\
\hline & Age Status & & \\
\hline 1. & 20-30 Years & 18 & 12.4 \\
\hline 2. & 31-40 Years & 23 & 14.7 \\
\hline 3. & 41-50 Years & 41 & 26.3 \\
\hline 4. & 51-60 Years & 54 & 35.2 \\
\hline \multirow[t]{3}{*}{5.} & 60 Years and Above & 20 & 12.8 \\
\hline & Total & 156 & 100.0 \\
\hline & Occupational Status & & \\
\hline 1. & Student & 10 & 6.4 \\
\hline 2. & Trader & 50 & 32.2 \\
\hline 3. & Farmer & 94 & 60.3 \\
\hline \multirow[t]{3}{*}{4.} & Civil Servant & 5 & 3.2 \\
\hline & Total & 156 & 100.0 \\
\hline & Annual Income & & \\
\hline 1. & Below N 100,000 & 10 & 6.4 \\
\hline 2. & $100,000-200,000$ & 15 & 9.6 \\
\hline 3. & $200,001-300,000$ & 94 & 60.3 \\
\hline 4. & $300,001-400,000$ & 29 & 18.5 \\
\hline 5. & $400,001-500,000$ & 5 & 3.2 \\
\hline \multirow[t]{2}{*}{6.} & 500,000 and Above & 3 & 2.0 \\
\hline & Total & 156 & 100.0 \\
\hline
\end{tabular}

Source: Author's field work, 2014

\subsection{Regularity of Movement in and out of Akutupa-Kiri}

The analysis of movement in and out of Akutupa-Kiri revealed that $52.0 \%$ of the respondents travelled regularly along Akutupa-Kiri road. Meanwhile, the purpose of movement as revealed from the findings shows that $27.2 \%$ of respondents' travels in and out of the study area for commercial and health purposes respectively. Moreover, the means of road transport available to commuters in the area are Okada (motorcycle), car and bus. The use of okada (motorcycle) and bus is the dominant means among the available means of road transportation in the area. The bus are usually patronized more, particularly during the dry season while, okada remains the dominant means of movement during the rainy season and is the only available means of transportation that provides door-to-door service which can easily traversed the area most especially during rainy seasons, because of the poor condition of the road to the area.

The above situation has been elucidated by Rietveid (2001) when he accentuated the factors that have attracted the use of motocycles in major location around the world to include among others: (i) to complement the concept of multi modal transport chains; (ii) serve as are cheap transport mode; and (iii) provide door-to-door transport. More importantly, the untired nature of the Akutupa-Kiri road has also increased the rate of patronage particularly during the rainy seasons when it may be difficult to access by cars and buses. The cost of travel along the axis in the study area also varies. However, it depends on the modal choice. Findings show that $49.4 \%$ of the commuters spent above $N 1200$ on the average to travel. This has been one of the major impediments to healthcare service delivery in the area as majority of the respondents describe the condition of the road as very poor. The situation above has compelled majority (95.0\%) in 
the area to patronize the tradio-medical practitioners as an alternative remedy to health care delivery.
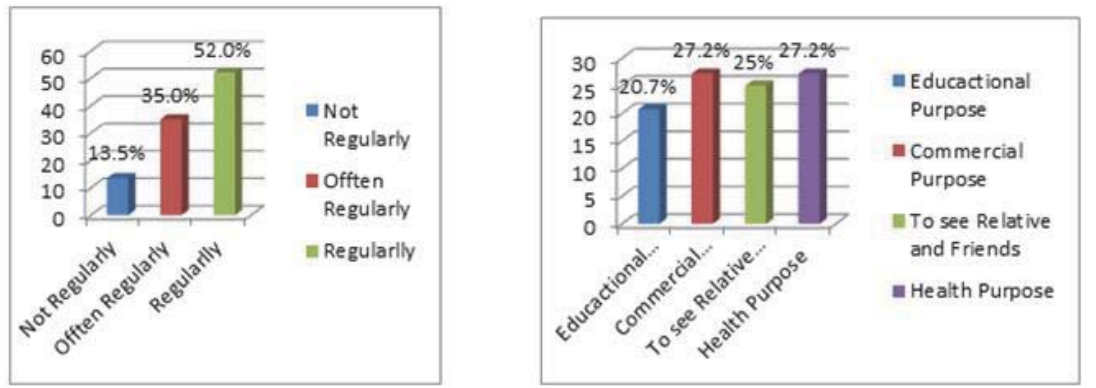

Figure 1A: Regularity of Movement in the Area. Figure 1B: Purpose of Movement in the area

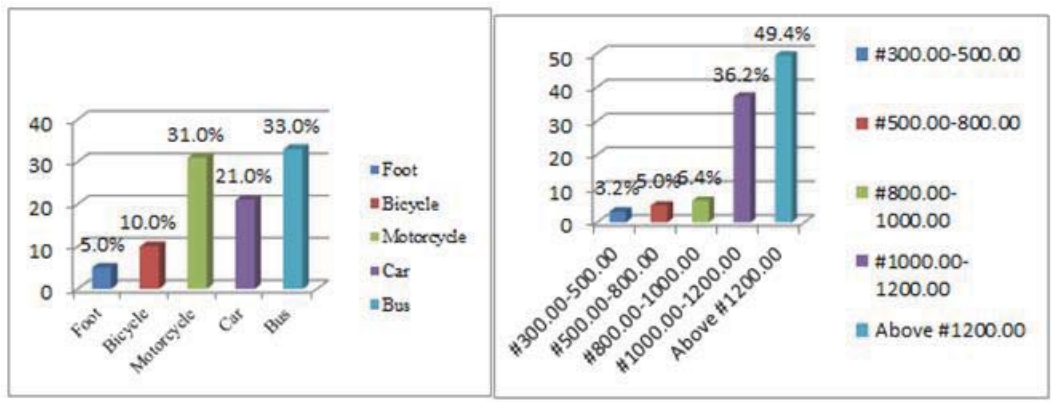

Figure 1C: Means of Transport in the Area Figure 1D: Cost of Movement in the Area.

Source: Author's field work, 2014

\subsection{Availability of Rural Transport Infrastructures in the Area}

Rural Transport Infrastructure (RTI) commonly referred to as rural roads, tertiary roads, district roads, local government council roads, feeder roads and access roads. (Lebo and Schelling, 2001; Ali, 2013). It also includes tracks, and paths commonly known as community roads with facilities such as drainage system/channel, road sign, foot bridges, bus stop shelter etc. (Ali, 2013). Based on personnel observation, it was discovered that Akutupa-Kiri road characterized by inadequate road infrastructures and this is attributed to the untarred nature of the road. The available road infrastructures in the area include foot bridges, road sign, and culvert. Although some of the aforementioned road infrastructures are dilapidated to the extent that they are impassable. For instance, the entire drainage/culvert channel has been blocked due to lack of proper maintenance. This situation has worsened the condition of the road as most passengers and drivers struggle to ply the road particularly during the rainy season.
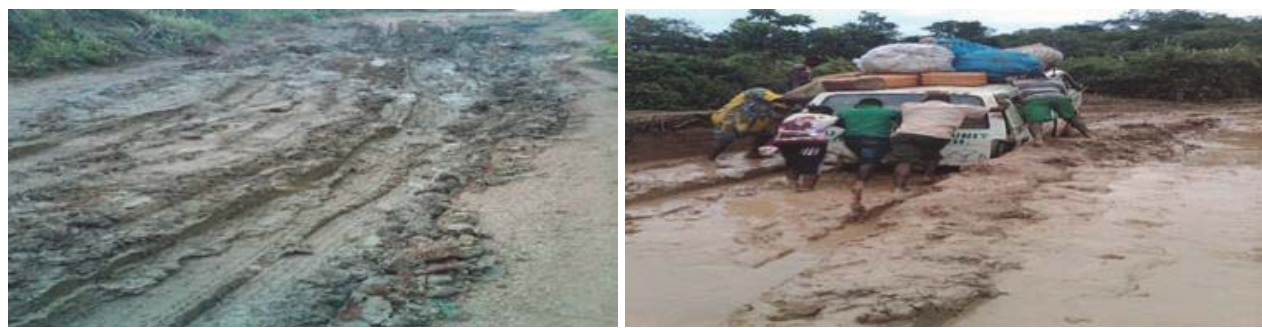

Plate 1: Road condition of Akutupa-Kiri

Source: Author's field work, 2014 
In conjunction with the above findings, the senior health officer in charge of the cottage hospital Akutupa-Kiri, in an interviewed noted that lack of basic infrastructures such as electricity, good water, paved/tarred road, commutations network (e.g. Glo, MTN, Airtel e.t.c) have hindered and as well prevented many of the medical officers to staying within the vicinity of Akutupa-Kiri. He further stated that lack of the basic infrastructures coupled with the poor state of the road has negated their operational performances.

\subsection{Level of Patronage of Akutupa-Kiri Cottage Hospital}

The analysis of the level of patronage of Akutupa-Kiri cottage hospital reveals that $88.2 \%$ of the respondents do not patronized the hospital and $12.2 \%$ claimed to have patronized the hospital. The reasons for the low level of patronage of the hospital according to the respondents includes: inadequate health personnel or professional, poor services and inadequate healthcare facilities. Although, $60.0 \%$ of the respondents opined that inadequate health personnel at the cottage hospital is the major reason that prevent them from patronizing the center. Inadequacy of healthcare facilities is also a problem at the centre. Meanwhile, it has been argue by Fatoke, (2013), that level of patronage of a particular health centre has to do with the level of available trained personnel, efficient service delivery and quality of healthcare facilities. He is of the opinion that quality of health personnel and facilities available will determined the type of services to be rendered to the people. The reason for not availability of health personnel is in connection with the problem of transportation which has discouraged health care workers from being posted to rural health care centres

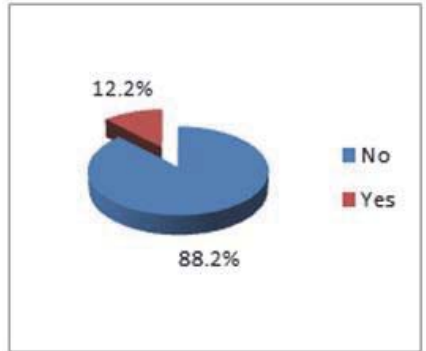

Figure 2A: Patronage of the Hospital

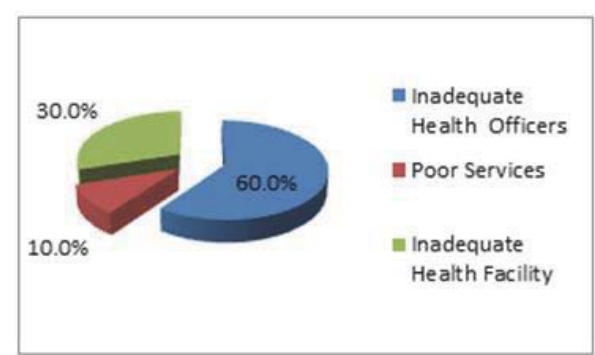

Figure 2B: Reasons for Non- Patronage of the Hospital

Source: Author's field work, 2014

\subsection{Patronage of Tradiomedical Care}

The figure below reveals that $64.1 \%$ of the respondents' patronized tradio-medical care while $36.0 \%$ do not patronized tradio-medical care in the area. From the analysis it is revealed that majority of the respondents in the study area patronized tradio-medical care. Findings show that $21.0 \%$ patronized the tradio-medical care due to the cheap cost of treatment, $20.0 \%$ of the respondents believed that it has spiritual backing while $95.0 \%$ affirmed to the high cost of transport to the city's' hospital. From the above, it was revealed that majority of the respondents in the study area patronized tradio-medical care purposely because of the high cost of transportation to the city. In agreement with the findings, Anita et al (2014) opined that lack of adequate and affordable transport services particularly in remote rural and marginalized areas, under-girded by sound transportation infrastructures, are obstacles to achieving meaningful healthcare service delivery. In the same vein, Fatoke (2013) noted that area that is highly dispersed and characterized by poor road condition, people there resolve to patronize herbalist or tradio-medical care centres for their survival due the high cost of transport required to the city's hospital. 

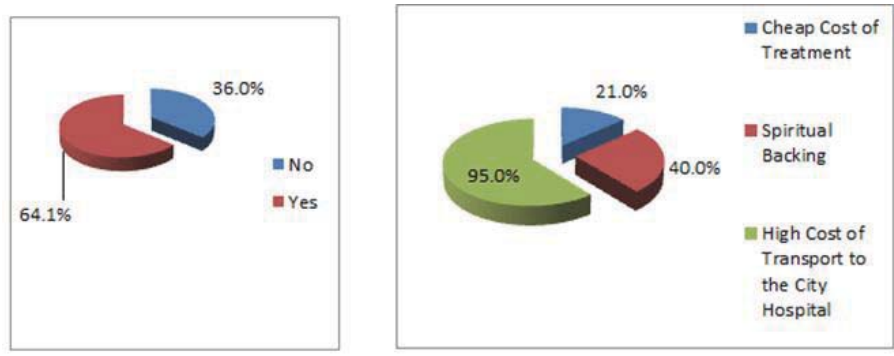

Figure 4A: Patronage of Tradiomedical Care Figure 4B: Reasons for Patronage

Source: Author's field work, 2014

\subsection{Problems face Rural Health Worker}

Fatoke, (2013) observed that problems of transportation to and within rural areas in Nigeria are major problems that affect the ability of health workers to deliver quality health services. It has been reported that there are not enough vehicles for workers to perform their task coupled with the poor state of rural road infrastructures in Nigeria. The information received from the senior health officer of Akutupa-Kiri cottage hospital shows that inadequate public and private transport, inadequate healthcare facility, delay in transfer of patients' as a result poor road and lack of communication have been the major problems confronting the health workers in the hospital. In fact, according to him, the above problems have led to the shortage of staff in the hospital. Based on the information received, the number of staff currently serving in the hospital is six from which two (2) possessed primary school certificate and secondary school certificate respectively, one (1) possessed National Diploma in Pharmacy technology and the other staff who is the senior officer in the hospital possessed Registered Nurses certificate. This information revealed that Akutupa-Kiri cottage hospital is short of qualified staff and this has seriously affected the level of patronage of the hospital. He stated further that the reasons for the shortage of staff in the area can be attributed to the fact that Akutupa-Kiri lack basic social amenities such as good road, potable water, market, electricity, communication network etc. that could have aided conducive environment for health workers in the area. The absence of the basic amenities has made many of staff to influence their posting back to town where they can enjoy basic amenities and conducive atmosphere. This has led to too much concentration of medical personnel in the urban areas to the neglect of the rural areas (Abdulraheem et al, 2012). The step taken to ameliorate the challenges according to the senior health officer of Akutupa-Kiri is partnerships with the community through the community leaders to sand-fill some of the impassable sport on the road to easy movement of vehicle in the area. He opines that since the period the road had been abandoned, no assistance was received from the local, state and federal government to finish abandoning part of the road. He emphasized that poor access road coupled with inadequate healthcare facilities and shortage of staff in area has seriously affect the people of Akutupa-Kiri as many of them that could not afford the cost of transport to the city's hospital relied solely on self-treatment and tradio-medical care for the survival. He concluded that Akutupa-Kiri is endowed with fertile soil and other mineral resource that can transform the area but the untarred nature of the road coupled with inadequacy of road infrastructures has made it impossible for all the resource to be properly harnessed.

\subsection{Research Findings}

On the basis of the objectives of the research here are the major findings emanating from the study:

i. Majority (61.0\%) of the household in the area possessed first school leaving certificate

ii. Findings revealed that the people (60.3\%) of Akutupa-Kiri are farmers and traders respectively.

iii. Motorcycles and buses remain the dominant means of road transport in the area. Though motorcycles is highly used during the raining season because of the nature of the road during the season.

iv. Cost of transport in the area is very high because most of the respondents (49.4\%) spent above N1200.00 per trip. This has made some of the household in the area to rely on self-treatment and even patronized tradiomedical care services since they could not afford the transport cost to visit the city's hospital.

v. Despite the untarred nature of Akutupa-Kiri road, findings revealed that road infrastructures that could enhance movement and promote social and economic interaction are lacking. This has affected the proper 
utilization of the cottage hospital situated in the area in terms of staff strength and healthcare facilities

vi. Findings also revealed that absences of basic infrastructures (such as communication network, electricity, source of good water, market, good road etc) in the area have disallowed the health workers to stay and work in the hospital.

vii. Inadequate public and private transport, inadequate healthcare facility, delay in transfer of patients' as a result poor road and lack of communication have been the major problems confronting the health workers in the hospital.

\section{Conclusion and Recommendations}

The study considered rural road infrastructural challenges as an impediment to health care services delivery in KabbaBunu Local Government area of Kogi with a particular reference to Akutupa-Kiri village. The study findings revealed that the state of the road is terribly bad and is characterized by poor road infrastructures. Findings also shows that the cottage hospital in Akutupa-kiri is under staff and the reasons for that have been attributed to the lack of basic social amenities that can support the stay of the staff in the hospital. Most of the households find it harder to travel to get to healthcare and other services because of insufficient healthcare facilities, poor roads and high transport cost. Even though the road is motorable, transport services are unreliable and infrequent; where available, such services are for hire and the majority of rural inhabitants cannot afford them. It has also been revealed that no assistance was received from the local, state and federal government toward the grading or completion of the abandoned part of the road. However, to ensure high standard of living and good health condition in the area, effort should be made by government to see that the abandoning part of the road to Akutupa-Kiri is completed. This will make life easy for the people in the area and improve the quality of service of health workers. Moreover, the completion of the road will not only improve the standard of the living alone but will as well facilitate movement of people, agricultural produce and accentuate development that will brings about provision of basic social amenities that is lacking in the area.

To increase the level of patronage of Akutupa-Kiri Hospital, necessary facilities and qualify health personnel that are skillful in the profession should be employed to serve at the hospital. This will reduce the habitual self-treatment and patronage of tradio-medical care that is very rampant among the people. Poor leadership and corrupt practices among government officials have been the basis for unsuccessful implementation of most government policies and programmes on health care delivery.

\section{References}

Abdulraheem, I. S. Olapipo, A. R.and Amodu, M. O. (2012) Primary health care services in Nigeria: Critical issues and strategies for enhancing the use by the rural communities. Journal of Public Health and Epidemiology Vol. 4(1), pp. 5-13,

Adedeji, O (2011).Rural and Urban Regional Planning. Published by Environmental Management \& Toxicology- COLERM_UNAAB_ Abeokuta

Adejuyigbe, O. (1973). Location of Social Science Centre in Western Nigeria, the case of Medical Facilities, Man and Society, 1, 115142.

Ajadi, B. (2010) "Poverty Situation in Nigeria: An Overview of Rural Development Institutions" Pakistan Journal of Sciences Vol. 7 No. 5 Pp $351-356$.

Adereti, F. O. (2005). Rural Women's Access to Infrastructural Facilities in Rural Areas in Osun State . Social Science,18(3) 165- 170.

Adewole, E.A (2013).The Regional Development Implications of Cassava Production in Ikere-Ekiti, Nigeria. Unpublished Master Dissertation Seminal Proposal of Department of Urban and Regional Planning, Federal University of Technology Akure.

Adeyemo, D.O. (2005). Local Government and Health Care delivery in Nigeria: A Case study. Journal of Human Ecology, 2, 149 - 160.

Agbola, T. and Agunbiade, E. (2007), Urbanization, Slum Development and Security of Tenure: The Challenges of Meeting Millennium Development Goals (MDG) 7 in Metropolitan Lagos, Nigeria PRIPODE Workshop on Urban population, Development Countries.

Alabi, M.O (2011).Towards Sustainable Distribution of Health Centers Using GIS: A Case Study from Nigeria. American Journal of Tropical Medicine and Public Health 1(3): 130-136, 2011

Aloba, O. (1985). Rural Transportation Planning in Nigeria: Some Implications for Regional Development. In Abiodun, J. O. (Ed.) Urban and Regional Planning Problems inNigeria. Ife: University of Ife Press Ltd.

Ali, A.N (2013).Constraints to Sustainable Rural Transport Infrastructure Development in Enugu State, Nigeria. Journal of Sustainable Development in Africa Volume 15, No 2

Annabel, D. (2000).Transport And Sustainable Rural Livelihoods in Zambia: A Case Study. Egypt Social Fund for Development Transport Research Laboratory

Anita, O.B, Irene, A and Prince, A. D (2014). The Contribution of Transport (Road) In Health Care Delivery "A Case Study Of Mankranso District Hospital In The Ahafo Ano South District Of Ashanti Region". British Journals of Marketing Studies Vol.2, No.4, Pp. 30-51

Aregbeyan, J. B. O. (1992). Healthcare service utilization in Nigeria Rural Communities, A focus on Otuo Community and Environs in 
Edo State. NISER Monography Series, Ibadan.

Basorun J.O (2004). Basic Element of Urban and Regional Planning. Akure Shalom Publisher.

Barjis, J., Gwendolyn, K and Johan, M (2013).A sustainable and affordable support system for rural healthcare delivery. Elsevier Decision Support Systems 56, 223-233

Chambers, R (1983). Rural Development: Putting the Last First. Longman, London.

Chariotmender (2008). Defination of transferability in spatial geography? Retrieve on $3^{\text {rd }}$ September, 2014 at http://www.answers.com/ topic/transferabi or http://faculty.washington.edu/jwh/207lec.

Ellis, S.D (1997).Key Issues in Rural Transport in Developing Countries. Published Transport Research Laboratory Old Wokingham Road Crowthome, Berkshire,RG456AU

Ele, C. (2006) Evangelization through Rural Development. Nsukka: Great AP Publishers Ltd.

Fatoke, O (2013). Assessment of Accessibility of Rural Women to Healthcare Facilities in Ola-Oluwa Local Government Area, Osun State, Nigeria. Unpublished Master Dissertation Seminal Proposal of Department of Urban and Regional Planning, Federal University of Technology Akure.

Humphreys J.S, (2002): Health service models in rural and remote Australia, in D. Wilkinson and I Blue, the New Rural Health: An Australian Text, Oxford University Press, 2002, 273-296.

Iyagba A. G. and.Anyanwu S.O (2012). Problems and prospects of cassava production in Rivers State, Nigeria: A case study of Oyigbo local government area. Agriculture and Biology Journal of North America.

Ken, G. (2011). African's Transport Infrastructure: Mainstreaming Maintenance and Management. Published by The International Bank for Reconstruction and Development/ World Bank, Washinton DC.

Labo J. and Schelling D (2001): Design and Appraisal of Rural Transport Infrastructure, Ensuring Basic Access for Rural Communities World Bank Technical Paper No 496. The World Bank, Washington D.C

Nwuke, K. (2004) "Poverty Reduction Strategies Towards The Millennium Development Goals:Africa's Experiences and Lessons for Nigeria". Paper delivery at the Enugu Policy Forum Organized by African Institute for Applied Economics, Enugu.

National Population Census (1991). Compressive Result of 1991Population census. Received Kabba-Bunu Local Government Population Office, Kabba Nigeria.

Nyagba, S. (2009) "Review of Nigeria's Rural Development Policy for sustainable Development" paper presented at Business Round Table at Abuja, 9 - 11 July.

Ogbuu C. I. (2008). Road Transportation Management and Customers Satisfaction. Published project dissertation of Department of Business Administration, Faculty of Management and Social Science Caristas University Amorji-Nike Enugu.

Okakunori, O.K. (2006). Transportation Management. Enugu, Grovani Publishers.

Okoko E.E. (2006). Urban Transportation Planning and Modeling. Akure, Millennium Publisher.

Okoko, E. (2011).Rural Transportation and Rural Development:The Instance of Akwapim South District in Ghana International Journal of Economic Development Research and Investment Vol 2 No. 3, 10-26

Okoli, F. and Onah, F. (2002) Public Administration in Nigeria: Nature, Principles and Application. Enugu: John Jacobs Publishers Ltd.

Okoye, C. (2000) "Democracy - Development Rhetoric in Nigeria: A Critical Discourse". African Political Science Review. Vol. 7 No 7 (Pp. $83-99)$.

Olaogun, A. E. (2006). Effects of Mothers' Socio-Economic Status on the management of Febbrile Condition in their Under-Fivein a Resource -Limited Setting. International Health and Human Rights, 6(1), 56-61.

Olarenwaju D.O. (1996). Social and Economic Deprivation in a Medium-Sized Urban Centre in Nigeria. HABITAL INTL. 20. NO. 2 PP229-240. Published by Elservier Science Ltd in Great Britain.

Olawole M. O., Aloba O. and Adetunji M. A. (2010). The Place of Transport in the Attainment of the Millennium Development Goals in Rural Areas of Nigeria. Ife Journal of Environmental Design and Management. 4 (1), 33 - 48.

Olujimi, J. A. (2003). Significant Factors Affecting Patronage Of Health Facilities by Rural Dwellers in Owo Region. The social Science Journal, 1(3), 206-215.

Olorunfemi S.O and Basorun J.O.(2013). Appraisal of Regional Mobility in Lokoja, Nigeria. Journal of Society and Communication pg 420-446

Olorunfemi S.O (2013).Assessment of On-Street Parking in Lokoja, Nigeria. Unpublished Master Thesis, Department of Urban and Regional Planning, Federal University of Technology Akure, Nigeria

Omoleke (2005). PHC services in Nigeria. - Constraints to optimal performance. Niger. J. Med., 14(2): 206-12.

Rietveid, P. (2001). "Biking and Walking: The Position of Non-Motorized Transport Modes in Transport System and Traffic Control, United Kingdom, Pergamon.

Sibiri, A. E., Ayinmoro, A. D, Jack Jackson, T. C. B (2014).The Socio-Cultural Effects of Internal Migration among the People of Akutupa Kiri in the North-Central Zone, Nigeria. Mediterranean Journal of Social Sciences, Vol 5, no 15.

Shoup, D. C. (2006). Cruising for parking. Transport Policy, 13, 479-486.

Ugwuanyi, B.I and Chukwuemeka, E.O (2013) Enhancing Rural Development in Nigeria: Periscoping the Impediments and Exploring Imperative Measures. Singaporean Journal of Business Economics, And Management Studies Vol.1, No.8, 2013.

World Bank. (2000). Rural roads and transport: Overview and conclusions from managing and financing rural transport infrastructure. Published by World Bank

Wunsch J.S, Olowu D (1996). Regime transformation from below: Decentralization, local governance, and democratic reform in Nigeria. J. Comp. Int. Dev., 31(4): 66-82. 